The Alexander Pope Encyclopedia, by Pat Rogers (366 pages, March 2004), offers 772 entries on English poet Alexander Pope (1688-1744) that cover his life, writings, correspondence, friends and enemies, themes and concerns, and literary techniques. One of the most quoted poets of the English language, Pope's The Rape of the Lock, Essay on Criticism, and Essay on Man include such gems as "To err is human, to forgive, divine" and "The proper study of mankind is man." This one-stop reference explains many of his allusions to contemporary English social mores, people, literature, and places in London. Lengthy entries are accompanied by a short reading list, and the book also contains a chronology, selected bibliography, and a useful index. \$99.95. Greenwood. ISBN 0313-32426-3.

The Book Nobody Read: Chasing the Revolutions of Nicolaus Copernicus, by Owen Gingerich (306 pages, March 2004), takes the reader on a quest to find all the extant copies of the first (Nuremberg, 1543) and

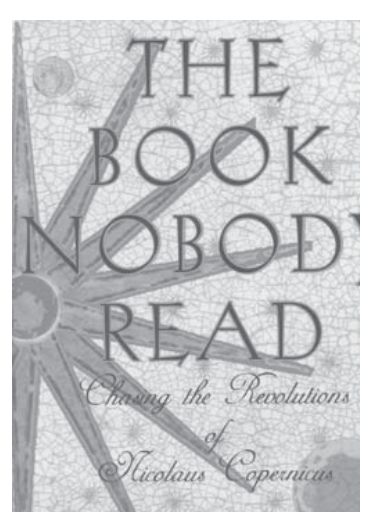
second (Basel, 1566) editions of De revolutionibus by Polish astronomer Nicolaus Copernicus. In 1970, Harvard astrophysicist Gingerich became fascinated with the greatest scientific book of the 16th century-the first to suggest that the earth revolved around the sun, yet one that Arthur Koestler in The Sleepwalkers (1959) alleged "nobody read" - and set out to prove, by examining the annotations in various copies, that it was in fact well-read by such astronomers as Galileo Galilei, Johannes Kepler, Erasmus Reinhold, Georg Joachim

George M. Eberhart is senior editor of American Libraries, e-mail: geberhart@ala.org
Rheticus, and many others. He ultimately examined 590 copies of the book, tracing ownerships, assisting in theft investigations, and demonstrating how an "intensely technical 16th-century treatise launched a revolution even more profound than the Reformation." A treasure for bibliophiles and a master work in the history of science. $\$ 25.00$. Walker \& Company. ISBN 0-8027-1415-3.

The Devil and the Land of the Holy Cross: Witchcraft, Slavery, and Popular Religion in Colonial Brazil, by Laura de Mello e Souza (350 pages, February 2004), originally published in Brazil in 1986, examines the uniquely Brazilian brand of magical religious culture that formed from the 16th to the 18th centuries as a blending of Iberian, African, and Indian beliefs. Mello e Souza explains the role of the Portuguese Inquisition in combating this popular religion, which expressed itself in divination, healing, talismanic magic, shape-shifting, animal familiars, sabbats, and spirit possession. $\$ 60.00$. University of Texas. ISBN 0-292-70228-0.

Digital Reference Services, edited by Bill Katz (331 pages, April 2004), is a well-chosen selection of ten articles on the basics and principles of digital reference, followed by ten case studies (nine of them in academic libraries) that offer practical ideas from real-time situations. Published simultaneously as number $79 / 80$ of The Reference Librarian, this monograph points out the caveats and challenges of answering queries in cyberspace. \$34.95. Haworth. ISBN 0-7890-2320-2.

Epic Films, by Gary Allen Smith (312 pages, 2d ed., May 2004), reviews 355 historical and mythological films set from prehistory through the Crusades. The majority are Greco-Roman or Biblical epics that have fascinated audiences since the early days of cinema. Smith has added more than 130 films since the first edition in 1991 and revised a number of entries that had received inadequate treatment. Accompanied by many 
stills of gladiators, slave girls, barbarians, and Romans in togas. \$49.95. McFarland. ISBN 0-7864-1530-4.

Essential Shakespeare Handbook, by Leslie Dunton-Downer and Alan Riding (480 pages, April 2004), offers clear commentaries on each of the Bard's 39 plays, complete with historical background and sources, dramatis personae, plot summaries, key quotations, literary significance, performance history, and an abundance of illustrations showing stage and film productions. Also included are chapters on Shakespeare's life and times, Elizabethan and Jacobean theatre, Shakespearean language, and the narrative and lyric poems. \$25.00. DK. ISBN 0-7894-9333-0.

History in Quotations, by M. J. Cohen and John Major (1,008 pages, January 2004), presents 9,000 quotations in 90 thematic chapters that focus on key periods, themes, or movements in world history, from ancient Mesopotamia to modern globalization. The authors have selected quotations that capture the spirit of the times, drawing on cuneiform tablets, dynastic annals, chronicles, state papers, legal judgments, letters, memoirs, newspapers, songs, plays, poems, and novels. The words are most often those of the participants or the witnesses to major events, such as Jean Froissart, who said in his Chronicles (1373) about the Black Death, "A third of the world died.” 30.00 . Cassell. ISBN 0-304-35387-6.

The History of Science and Technology, by Bryan Bunch with Alexander Hellemans (776 pages, April 2004), presents a year-byyear chronicle of discoveries and inventions from the first use of tools 2.6 million years ago to 2003. Each year's achievements are subdivided by such subjects as anthropology, archaeology, astronomy, biology, chemistry, communication, computers, construction, earth science, ecology and the environment, electronics, energy, food and agriculture, materials, mathematics, medicine and health, physics, tools, and transportation. Scattered throughout the chronology are brief biographies of prominent scientists and more than 100 short essays on significant events like the value of pi and the Human Genome Project. Bunch notes in the introduction that many of the essays and chronicle entries were originally included in Timetables of Science (1989) and Timetables of Technology (1993), which he cowrote with Hellemans, but there are significant changes and additions. The comprehensive index aids access. \$40.00. Houghton Mifflin. ISBN 0-618-22123-9.

\section{Magnificent Mihirungs: The Colossal} Flightless Birds of the Australian Dreamtime, by Peter F. Murray and Patricia Vickers-Rich (410 pages, March 2004), reviews the palaeontological data on the odd-looking

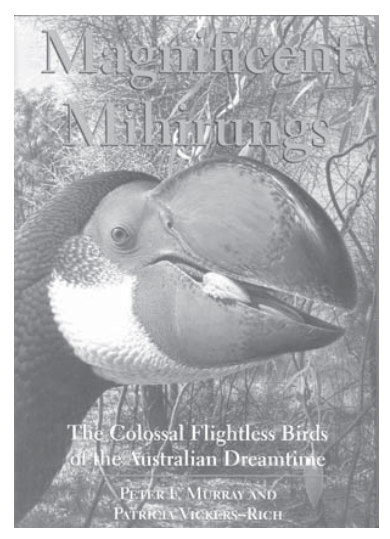
members of the extinct family Dromornithidae, huge relatives of geese that died out in Australia some 40,000 years ago. One species stood more than eight feet tall. The authors relate the discovery of the first fossils and describe the birds' classification, bone structure, appearance, posture, body mass, habitat, diet, and evolution. The name "mihirung" comes from an Aboriginal tradition of giant emus that lived in the Dreamtime. \$75.00. Indiana University. ISBN 0-253-34282-1.

("Civic engagement..." continued from page 388)

9. See the "By the People" Web site at www.pbs.org/newshour/btp.

10. Doble Research Associates, "Terrorism: What Should We Do Now? Results from Citizens Forums" (Dayton, OH: National Issues Forums Institute, 2003). www.nifi.org /terrorism_03.pdf.

11. Frances Moore Lappe, "Diet for a Small Planet" (New York: Ballantine Books, 1971).

12. Nancy Kranich, Anne Heanue and Taylor Willingham, "Libraries-Public Forums for Today's Critical Issues," American Libraries, 34, \#1 (January 2003): 68-70.

13. Kellogg Commission on the Future of State and Land Grant Universities, "Renewing the Covenant: Learning, Discovery, and Engagement in a New Age and Different

(continued on page 400) 